Article

\title{
Performance, Body Water Balance, Ingestive Behavior and Blood Metabolites in Goats Fed with Cactus Pear (Opuntia ficus-indica L. Miller) Silage Subjected to An Intermittent Water Supply
}

\author{
Italo Albuquerque ${ }^{1}$, Gherman Araújo 2 ${ }^{\mathbb{D}}$, Fernanda Santos ${ }^{1}$, Gleidson Carvalho ${ }^{1}$, \\ Edson Santos $^{3}$, Ismael Nobre ${ }^{3}$, Leilson Bezerra ${ }^{4}$, Jarbas Silva-Júnior ${ }^{1} \mathbb{D}$, Edson Silva-Filho ${ }^{5, * \mathbb{C}}$ \\ and Ronaldo Oliveira ${ }^{1, *}$ \\ 1 Veterinary Medicine and Animal Science Department, Federal University of Bahia, 500 Adhemar de Barros \\ Avenue, Salvador 40170110, BA, Brazil; italoreneu@hotmail.com (I.A.); nanda_nadinne@hotmail.com (F.S.); \\ gleidsongiordano@yahoo.com.br (G.C.); miguelreges@gmail.com (J.S.-J.) \\ 2 Brazilian Agricultural Research Corporation, Embrapa Semi-Arid, Petrolina 56302970, PE, Brazil; \\ gherman.araujo@embrapa.br \\ 3 Animal Science Department, Federal University of Paraiba, Areia City 58397000, Paraiba State, Brazil; \\ edson@cca.ufpb.br (E.S.); ismaelzootec@hotmail.com (I.N.) \\ 4 Center of Health and Agricultural Technology, Federal University of Campina Grande, \\ Patos 58708110, PB, Brazil; leilson@ufpi.edu.br \\ 5 Campus Ministro Petrônio Portela (CMPP), Chemistry Department, Federal University of Piauí, \\ Teresina 64049550, PI, Brazil \\ * Correspondence: edsonfilho@ufpi.edu.br (E.S.-F.); ronaldooliveira@ufba.edu.br (R.O.); \\ Tel.: +55-863-237-2059 (E.S.-F.); +55-719-9231-9378 (R.O.)
}

Received: 20 February 2020; Accepted: 30 March 2020; Published: 4 April 2020

\begin{abstract}
This study evaluated the performance, body water balance, ingestive behavior and blood metabolites in goats fed with cactus pear silage subjected to an intermittent water supply. Thirty-six goats were distributed in a randomized block design arranged as a $3 \times 3$ factorial with cactus pear silage in the goats' diet (on a $0 \%, 21 \%$ and $42 \%$ dry matter-DM basis) and water offer frequency (ad libitum, and 24 and $48 \mathrm{~h}$ water restrictions). There was an interaction only between the cactus pear silage level and water offerings for drinking water. Goats fed $42 \%$ cactus pear silage had greater intake of non-fibrous carbohydrates, energy, $\mathrm{Ca}, \mathrm{Mg}$ and Na minerals, water intake, urinary water excretion, body water retention and nutrient digestibility. Cactus pear silage inclusion up to a $42 \%$ rate reduced eating and ruminating time and increased the time spent idling as well as the eating and the ruminating efficiency rate. Water restriction at $48 \mathrm{~h}$ reduced drinking water intake. Performance and blood metabolites were not affected by cactus silage inclusion or water offering. Cactus pear silage inclusion at up to $42 \%$ for goats is recommended during periods of water shortage in semiarid and arid regions because it improves eating, the ruminating efficiency rate, and body water retention; cactus pear silage inclusion at this rate reduces water consumption and it does not affect the performance or health of the animals.
\end{abstract}

Keywords: caprine; silage; Opuntia ficus sp.; semiarid; water restriction

\section{Introduction}

Semiarid and arid regions around the world harbor large herds of small ruminants that are subjected to water and feed scarcity, which has intensified with the effects of climate change [1]. Water is important for goats and is essential at any rearing phase. The increasing scarcity of this precious 
natural resource has drawn concern from different segments of society, who seek solutions for rational and sustainable use of this resource [2]. The meat of small ruminants, such as sheep and goats, is a food source in many parts of the world, and the high adaptability of these animals in semiarid and arid areas allows them to use water efficiently [3,4].

Water restriction due to long periods of drought and rainfall irregularities have been reported to reduce feed intake and performance in sheep and goats [5]. Water can be supplied to animals in the form of a drink, feed and metabolic water from nutrient catabolism [6]. Bispo et al. [7], while investigating the feed of sheep, observed that water intake decreased from $3.25 \mathrm{~L} / \mathrm{d}$ to $0.44 \mathrm{~L} / \mathrm{d}$ when forage cactus pear was used as feed from 0 to $560 \mathrm{~g} / \mathrm{Kg}$ of dry matter (DM), substituting for elephant grass. Forage cactus pear is an excellent alternative for increasing water availability through feed [8-10] and is widely used as a feed ingredient in sheep diets in semiarid and arid regions because of its good adaptability to soil and weather conditions [11].

Despite the low DM production ( $<10 \%$ as fresh matter), cactus pear forage is an excellent source of dietary energy because of its non-fibrous carbohydrates (NFC $\pm 55 \%$ in DM) and total digestible nutrient (TDN) content; in addition, it has high water $( \pm 90 \%$ as fresh matter) and ash $( \pm 9 \% \%$ in DM) contents [12,13]. Cactus silage fermentation is dominated by lactic acid fermentation, resulting in a $\mathrm{pH}$ of approximately 4.0 and a low yeast content $[14,15]$. Considering the difficulties encountered in semiarid regions, such as the low availability of forage and water scarcity, we have hypothesized that the storage of juicy plants, such as cactus pear forage, becomes even more important because the nutritional value and water amount found in cactus pear silage could be a source of water to replace or save drinking water without affecting the performance growth of animals. Therefore, investigations into the ability of animals to adapt to these changes are needed. Thus, this study was conducted to test the hypothesis that cactus pear silage feeding can improve the water use efficiency during water restriction periods in goats, improving their performance without negative effects on their ingestive behavior or health.

\section{Materials and Methods}

All procedures involving animals were approved by the Ethical Principles for the Use of Animals for Scientific Purposes of the Federal University of Bahia (Permission number 04/2016), in accordance with the guidelines of the National Council of Control of Animal Experimentation (Brasília, Brazil; CONCEA). The experiment was conducted in the Experimental Field of Caatinga Biome, which belongs to the Brazilian Enterprise of Agriculture Research-Embrapa Semiarid and has the geographical coordinates $9^{\circ} 23^{\prime} 35^{\prime \prime}$ South and $40^{\circ} 30^{\prime} 27^{\prime \prime}$ West.

\subsection{Animals, Experimental Design and Duration}

Thirty-six castrated male crossbreed goats (F1 Boer $\times$ undefined breed) with an initial body weight (BW) of $18.2 \pm 7.23 \mathrm{Kg}$ and 8 months of age were distributed in a randomized block design, and treatments were arranged in a $3 \times 3$ factorial, using three levels of cactus pear silage $(0,21$ and $42 \% \mathrm{DM}$ total) and intermittent daily offers of water (ad libitum) or water every 24 or $48 \mathrm{~h}$ (water restriction).

The experimental period lasted $75 \mathrm{~d}$, preceded by $12 \mathrm{~d}$ of adaptation of the animals to the environment, with intermittent offers of water and feeding. The goats were identified, weighed and treated to control internal and external parasites in the adaptation period.

\subsection{Silage Cactus Pear and Qualitative Characteristics}

The cactus pear (Opuntia ficus sp.) used in the experiment to make the silage was obtained from a cactus pear plantation. The cactus plants were more than four years old and were obtained from a single producer. The plants were cut and moved to Embrapa Semiárido (Brazil), where they were cut to $3.0 \mathrm{~cm}$, processed in a shredder and stored in polyethylene plastic tubs with a $200 \mathrm{~L}$ capacity and without additives. The silos were covered with plastic and sealed with lids to promote the fermentative process; the silage was used after a minimum period of $60 \mathrm{~d}$ after its confection. 
The fermentation profile of silage was realized in mini-silos (polyvinyl chloride tubes with $5 \mathrm{~L}$ capacity, $100 \mathrm{~mm}$ in diameter and $50 \mathrm{~cm}$ in length) coupled with a Bunsen-type valve on the lid to evaluate the output of gases and a thin area layer at the base to measure losses. The $\mathrm{pH}$ was determined according to Jobim et al. [16]. The dry matter content and recovery, losses from the effluent and gases were quantified using the following equation proposed by Jobim et al. [16]. The ammonia nitrogen $(\mathrm{mg} / \mathrm{g}$ total $\mathrm{N})$ content was determined as described by Bolsen et al. [17]. The lactic, acetic, propionic and butyric acid analysis was performed according to Kung and Shaver [18]. The samples were centrifuged at 13,000 $\times \mathrm{g}$ for $15 \mathrm{~min}$ for readings in a high-performance liquid chromatograph (HPLC), Shimadzu brand, coupled to an ultraviolet (UV) detector model SPD-10A VP at a wavelength of $210 \mathrm{~nm}$. A reverse phase $\mathrm{C} 18$ column with a pressure of $168 \mathrm{Kg}$ force $(f)$ and a flow rate of $1.5 \mathrm{~mL} / \mathrm{min}$ was used.

\subsection{Diets and Chemical Composition}

The diets were composed of different concentrations of cactus pear silage, Tifton- 85 grass hay and concentrate (created with corn bran, soybean meal, wheat bran and a mineral part). Diets were formulated to meet the nutritional requirements of crossbred goats with estimated weight gain of $100 \mathrm{~g} / \mathrm{d}$ following the National Research Council [6] recommendations. The ratio of roughage:concentrate was $60 \%: 40 \%$, but the concentrations of cactus pear silage were offered at volumes of $0 \%, 21 \%$ and $42 \%$. The ingredient composition is presented in Table 1, and the mixtures of ingredients in different diets and diet composition are in Table 2.

Feed was provided in two daily meals, at 9:00 and 15:00 h, and the amount of feed was adjusted daily with an acceptable refusal amount corresponding to $10 \%$ of the total amount supplied to ensure ad libitum intake. Samples of ingredients of the diets and from the concentrations and refusals were collected weekly and frozen $\left(-20^{\circ} \mathrm{C}\right)$ for further chemical analysis.

The samples were then thawed, pre-dried at $55^{\circ} \mathrm{C}$ for $72 \mathrm{~h}$ and ground to pass through a 1-mm sieve using a Wiley mill (Tecnal, Piracicaba City, São Paulo State, Brazil), before being stored in properly sealed airtight plastic containers (model SR941, Sanremo, Esteio city, RS state, Brazil) until subsequent laboratory analysis. Laboratory analyses were performed according to the Association of Official Analytical Chemists (AOAC) [19] for dry matter (DM, method 930.15), crude protein (CP, method 968.06), ether extract (EE, method 954.05), and crude ash (method 942.05).

Analyses for the determination of neutral detergent fiber (NDF) and acid detergent fiber (ADF) were performed according to Van Soest et al. [20], with modifications proposed by Senger et al. [21] for the use of an autoclave. The autoclave temperature was maintained at $110{ }^{\circ} \mathrm{C}$ for a period of $40 \mathrm{~min}$. The samples were treated with thermostable alpha-amylase without the use of sodium sulfite. Neutral detergent insoluble nitrogen (NDIN) and acid detergent insoluble nitrogen (ADIN) values were obtained following the recommendations of Licitra et al. [22]. The NDF residue was incinerated in an oven at $600^{\circ} \mathrm{C}$ for $4 \mathrm{~h}$, and the protein correction ( $\mathrm{NDF}_{\mathrm{ap}}$ ) was determined by subtracting the NDIN. Acid detergent lignin (ADL) contents were determined by using ADF residue treated with $72 \%$ sulfuric acid [19].

The NFC content was determined as proposed by Mertens (Equation (1)) [23]:

$$
N F C\left(\frac{g}{K g}\right)=100-N D F_{a p}-C P-E E-\text { crude ash }
$$

The contents of calcium $(\mathrm{Ca})$, phosphorous $(\mathrm{P})$, magnesium $(\mathrm{Mg})$, potassium $(\mathrm{K})$ and sodium $(\mathrm{Na})$ of ingredients and diets were determined in a mineral solution obtained by distillation. For $\mathrm{Ca}$ and $\mathrm{Mg}$ minerals, atomic absorption spectrophotometry was used; $\mathrm{P}$ was determined with colorimetry while $\mathrm{Na}$ and $\mathrm{K}$ were determined by flame spectrophotometry according to AOAC [19]. 
Table 1. Chemical composition of the experimental ingredients and cactus pear silage quality.

\begin{tabular}{|c|c|c|c|c|c|}
\hline Item & Corn Bran & Soybean Meal & Wheat Bran & Cactus Pear Silage & Tifton-85 \\
\hline \multicolumn{6}{|l|}{ Chemical Composition ( $\mathrm{g} / \mathrm{Kg}$ dry matter) } \\
\hline Dry matter $(\mathrm{g} / \mathrm{Kg}$ as fed $)$ & 881 & 852 & 848 & 96.9 & 864 \\
\hline Crude ash & 39.2 & 47.3 & 78.8 & 98.5 & 104 \\
\hline Crude protein & 92.4 & 490 & 185 & 53.1 & 78.6 \\
\hline NDIN $^{1}$ (g/Kg crude protein) & 218 & 112 & 16.4 & 24.5 & 397 \\
\hline $\mathrm{ADIN}^{2}$ (g/Kg crude protein) & 99.8 & 60.2 & 51.4 & 7.50 & 70.6 \\
\hline Ether extract & 41.0 & 17.5 & 34.5 & 18.8 & 17.9 \\
\hline Neutral detergent fiber $_{\mathrm{ap}}{ }^{3}$ & 124 & 144 & 427 & 291 & 738 \\
\hline Acid detergent fiber & 49.7 & 96.8 & 126 & 208 & 399 \\
\hline Non-fibrous carbohydrates & 703 & 300 & 274 & 539 & 61.4 \\
\hline Hemicellulose & 74.6 & 47.7 & 301 & 82.0 & 339 \\
\hline Acid detergent lignin & 13.5 & 18.5 & 37.5 & 52.1 & 84.5 \\
\hline \multicolumn{6}{|l|}{ Macrominerals (g/Kg dry matter) } \\
\hline Calcium (Ca) & 38.3 & 25.2 & 33.2 & 93.1 & 10.4 \\
\hline Phosphorus (P) & 10.6 & 60.6 & 12.7 & 8.50 & 13.6 \\
\hline Magnesium $(\mathrm{Mg})$ & 16.3 & 29.1 & 17.1 & 42.6 & 31.8 \\
\hline Sodium $(\mathrm{Na})$ & 30.0 & 60.0 & 30.0 & 80.0 & 30.0 \\
\hline Potassium (K) & 7.00 & 18.0 & 5.00 & 6.00 & 6.00 \\
\hline \multicolumn{6}{|l|}{ Qualitative characteristics of cactus silage } \\
\hline $\mathrm{pH}$ & - & - & - & 3.81 & - \\
\hline Effluent loss (Kg/t fresh matter) & - & - & - & 22.8 & - \\
\hline Gas losses (g/Kg dry matter) & - & - & - & 59.2 & - \\
\hline Dry matter recovery ( $\mathrm{g} / \mathrm{Kg}$ of feed) & - & - & - & 923 & - \\
\hline $\mathrm{N}-\mathrm{NH}_{3}$ (mg/g nitrogen) & - & - & - & 9.00 & - \\
\hline Lactic acid (mg/Kg dry matter) & - & - & - & 80.2 & - \\
\hline Acetic acid (mg/Kg dry matter) & - & - & - & 22.5 & - \\
\hline Propionic acid (mg/Kg dry matter) & - & - & - & 8.10 & - \\
\hline Butyric acid (mg/Kg dry matter) & - & - & - & 0.50 & - \\
\hline
\end{tabular}

${ }^{1} \mathrm{NDIN}=$ Neutral detergent insoluble nitrogen; ${ }^{2} \mathrm{ADIN}=$ Acid detergent insoluble nitrogen; ${ }^{3} \mathrm{NDF}_{\mathrm{ap}}=$ Neutral detergent fiber corrected for ash and protein. 
Table 2. Ingredient proportions and chemical composition of the experimental cactus pear silage diets.

\begin{tabular}{|c|c|c|c|}
\hline \multirow{2}{*}{$\begin{array}{c}\text { Item } \\
\text { Ingredients }(\mathrm{g} / \mathrm{Kg} \text { dry matter) }\end{array}$} & \multicolumn{3}{|c|}{ Inclusion of Cactus Pear Silage in Diet (g/Kg DM) } \\
\hline & 0 & $21 \%$ & $42 \%$ \\
\hline Cactus pear silage & 0.00 & 210 & 420 \\
\hline Corn bran & 310 & 270 & 130 \\
\hline Soybean meal & 70.0 & 90.0 & 90.0 \\
\hline Wheat bran & 10.0 & 30.0 & 170 \\
\hline Mineral mixture & 10.0 & 10.0 & 10.0 \\
\hline Tifton- 85 grass & 600 & 390 & 180 \\
\hline \multicolumn{4}{|l|}{ Chemical composition ( $\mathrm{g} / \mathrm{Kg}$ dry matter) } \\
\hline Dry matter $(\mathrm{g} / \mathrm{Kg}$ as fed $)$ & 870 & 707 & 542 \\
\hline Crude ash & 98.7 & 78.4 & 82.9 \\
\hline Crude protein & 112 & 116 & 124 \\
\hline Neutral detergent insoluble nitrogen, $\mathrm{g} / \mathrm{Kg} \mathrm{CP}{ }^{1}$ & 314 & 230 & 123 \\
\hline Acid detergent insoluble nitrogen, $\mathrm{g} / \mathrm{kKg} \mathrm{CP}{ }^{1}$ & 78.0 & 63.0 & 42.9 \\
\hline Ether extract & 25.0 & 24.6 & 23.9 \\
\hline Neutral detergent fiber $a p\left(N_{a p}{ }^{2}\right)$ & 496 & 408 & 357 \\
\hline Acid detergent fiber & 263 & 225 & 196 \\
\hline Non-fibrous carbohydrates & 279 & 372 & 412 \\
\hline Hemicellulose & 233 & 183 & 161 \\
\hline Acid detergent lignin & 55.3 & 50.3 & 46.9 \\
\hline \multicolumn{4}{|l|}{ Macrominerals (g/Kg DM) } \\
\hline Calcium $(\mathrm{Ca})$ & 40.4 & 61.0 & 78.0 \\
\hline Phosphorus (P) & 24.4 & 24.4 & 22.4 \\
\hline Magnesium (Mg) & 32.1 & 34.7 & 37.0 \\
\hline Sodium (Na) & 37.5 & 45.1 & 55.6 \\
\hline Potassium (K) & 7.60 & 7.70 & 7.50 \\
\hline Ca:P ratio & $1.65: 1$ & $2.50: 1$ & $3.48: 1$ \\
\hline
\end{tabular}

\subsection{Intake, Performance and Digestibility}

Nutrient intake was estimated by calculating the difference between the total of each nutrient contained in the feed offered and the amount in the refusals. The goats were individually weighed at the beginning and at the end of the experiment, always in the morning after $16 \mathrm{~h}$ of fasting. At the end of the experimental period, the final body weight (FBW) was obtained. The total weight gain (TWG) was also calculated as the difference between FBW and the initial BW, and the average daily gain (ADG) was calculated by dividing the results by the number of days of feedlot. The feeding efficiency was calculated as the ADG:DMI ratio (g/g).

The digestibility trial was conducted using 18 goats in metabolic cages (six replicates) individually fed the same diet and subjected to intermittent water supply for $20 \mathrm{~d}$, with $15 \mathrm{~d}$ of adaptation to the metabolic cages. Feces collection occurred on 5 consecutive $d$ (between the $40^{\text {th }}$ and $45^{\text {th }} d$ ) following adaptation to metabolic cages. Collected samples were frozen for further analysis. For the collection of total feces, collection bags were attached to the goats, and samples were collected twice a day, at 09:00 and 15:00 $\mathrm{h}$. The samples were weighed and homogenized, and approximately $10 \%$ of the total sample volume was retained for subsequent laboratory analyses. Total urine was collected with a bucket collector in the metabolic cage, which contained sulfuric acid solution (required to maintain the final $\mathrm{pH}$ below three) in a proportion equal to $10 \%$ of the total volume of urine from the previous day. The DM, $\mathrm{CP}, \mathrm{EE}, \mathrm{NDFap}, \mathrm{NFC}$ and TDN digestibility coefficients were calculated using the following equation:

$$
N D=\left[\frac{(I n-E x)}{I n}\right] \times 100
$$

where, $N D$ is Nutrient Digestibility $(\mathrm{g} / \mathrm{Kg} \mathrm{DM})$, $I n$ is ingestion (Kg of ingested nutrient) and $E x$ is excretion (Kg of excreted nutrient). 


\subsection{Body Water Balance in Goats}

The water intake was measured by weighing the offered water in plastic buckets and subtracting the leavings after a $24 \mathrm{~h}$ period and the water lost by evaporation. The following formula was used (Equation (3)):

$$
D W=(O W-R O)-E O
$$

where, $D W$ is Drinking water $(\mathrm{Kg}), O W$ is Offered water $(\mathrm{Kg}), R O$ is refused water $(\mathrm{Kg})$ and $E O$ is evaporated water $(\mathrm{Kg})$

To calculate the amount of evaporated water, plastic buckets with water were randomly distributed in the same location of the bays where water was offered and weighed every $24 \mathrm{~h}$, thus calculating the average values of water loss per evaporation. Feeding water (FW) was calculated by determining the dry matter (DM basis) content of feed and refusals using the following Equation (4):

$$
F W=M S-M R
$$

where, $F W$ is feeding water $(\mathrm{Kg}), M S$ is moisture contained in the supply $(\mathrm{Kg})$ and $M R$ is moisture contained in refusals $(\mathrm{Kg})$. Total water intake was calculated by Equation (5):

$$
T W I=F W+D W
$$

and total water excretion was calculated by Equation (6):

$$
T W E=U W E+F W E
$$

where, $T W E$ is total water excretion ( $\mathrm{Kg} /$ day), $U W E$ is urine water excretion (as DM basis, $\mathrm{Kg} /$ day) and FWE is feces water excretion (as DM basis, $\mathrm{Kg} /$ day). The values of $U W E$ and $F W E$ were calculated by means of DM analysis (AOAC, 2012) and estimated by using the following Equations (7) and (8):

$$
\begin{aligned}
U W E & =\left(1-D M_{\text {urine }}\right) \\
F W E & =\left(1-D M_{\text {feces }}\right)
\end{aligned}
$$

Body water balance/retention $(B W B, \mathrm{Kg} /$ day) was calculated by subtracting the total water intake in relation to the total water excreted using the following formula (Equation (9)) [24]:

$$
B W B\left(\frac{\frac{K g}{\text { animal }}}{\text { day }}\right)=T W I-T W E
$$

\subsection{Ingestive Behavior}

Goats were subjected to individual visual observations at the 16th and 50th $d$ of the experimental period in five-minute intervals according to Martin and Bateson [25] by two trained observers per animal to evaluate ingestive behaviors (spent time eating, ruminating and idling). The nighttime observations were conducted using artificial lighting. The observers counted both the number of ruminating chews and the boli ruminated per day. For rumination, the chews were evaluated at three different periods of the day (10:00-12:00, 14:00-16:00 and 18:00-20:00 $\mathrm{h}$ ) using a digital chronometer [26]. Total chewing time (TCT) was calculated over three 15-second periods by multiplying the average number of chews by four to obtain the chewing time per minute. Eating and/or ruminating rates were calculated by dividing the DM and NDF intake by the total time spent in activity, expressed as $\mathrm{DM} / \mathrm{h}$ and g NDF/h, respectively [26]. 


\subsection{Blood Metabolites}

Blood samples were collected every $21 \mathrm{~d}$ from all goats; and samples were collected by jugular venipuncture in the morning before feeding [27]. Disposable needles $(25 \times 8 \mathrm{~mm} ; 21 \times \mathrm{g})$ were used, and $10 \mathrm{~mL}$ blood samples were placed in glass tubes without anticoagulant for biochemical tests. Metabolic parameters were analyzed, and the methods used were as follows (Labtest Diagnostic SA $₫$, Brazil): albumin was measured by bromocresol green; total protein concentration was measured by the biuret method; glucose concentration was measured by the GOD-Trinder method; triglycerides were measured by glycerol phosphate oxidase (GPO); total cholesterol was measured by the cholesterol enzymatic method; and globulin concentration was calculated by the mathematical difference between total protein and the albumin serum concentration. The laboratory analyses were determined by using the colorimetric method on a semi-automatic biochemical analyzer (BIOPLUS 2000®, São Paulo, Brazil).

\subsection{Statistical Analysis}

The experimental design was a randomized block design, blocked according to animal weight, and the treatments were arranged in a $3 \times 3$ factorial with three cactus pear silage inclusion levels $(0 \%$, $21 \%$ and $42 \% \mathrm{DM}$ ) and intermittent water offers (ad libitum, and 24 and $48 \mathrm{~h}$ water restriction) in the diets of goats.

The following mathematical (Equation (10)) model was used:

$$
Y i j k=\mu+\alpha i+\beta j+(\alpha \beta) i j+k+e i j k
$$

where $Y i j k$ is observed value; $\mu$ is overall average of the treatment; $\alpha i$ is effect of cactus pear silage levels $i, i$ is $0 \%$ (control), $21 \%$ and $42 \%$; $\beta j$ is effect of intermittent water offers $j ; j$ is ad libitum (control), $24 \mathrm{~h}$ and $48 \mathrm{~h}$ water restriction; $(\alpha \beta) i j$ is effect of the interaction of the levels of cactus pear silage and of intermittent water offers; and eijk is error random associated with each observation.

The studied variables were statistically treated by analysis of variance (ANOVA), followed by Tukey's test using PROC GLM-SAS® [28]. Significance was set at $p<0.05$.

\section{Results}

\subsection{Performance, Intake, Digestibility and Body Water Balance}

There was no interaction $(p>0.05)$ between the proportions of cactus pear silage and the intermittent offers of water on performance and nutrient intake of goats, so the data are presented and discussed separately (Table 3).

The intermittent offers of water did not influence performance growth or the nutrient intake of goats. The intake average observed for DM was $651 \mathrm{~g} /$ day, corresponding to $3.19 \%$ BW and 61.9 BW0.75. Cactus pear silage inclusion in the diets reduced NDFap intake and increased the intake of NFC and TDN (g/day). The intake of NDFap was greater $(p=0.02)$ in the diet without cactus pear silage than in the diets with $21 \%$ and $42 \%$ cactus pear silage.

The NFC was greater $(p<0.01)$ in the diets with greater proportions of cactus pear silage for animals that received $21 \%$ and $42 \%$ cactus silage in the diets, respectively, than in the diet without silage. The TDN was greater in the diet with $42 \%$ cactus pear silage than in diets with $0 \%$ and $21 \%$ cactus pear silage.

The intermittent offers of water did not influence the intake of minerals $(p>0.05)$. The intake of $P$ and $\mathrm{K}$ was not influenced $(p>0.05)$ by the inclusion of cactus pear silage in the diets. However, $\mathrm{Ca}, \mathrm{Mg}$ and Na intakes and the Ca:P ratio showed an effect with the increase in cactus pear silage in the goats' diet. Cactus pear silage elevated the Ca intake $(p<0.01)$ for the animals that received $42 \%$ cactus pear silage, which was greater than the intake in goats without and with $21 \% \mathrm{DM}$ silage inclusion in the diets. The Mg intake was greater $(p<0.01)$ in goats that received greater proportions of cactus pear silage ( $21 \%$ and $42 \% \mathrm{DM})$ than in goats that were not fed cactus pear silage. Regarding Na intake, 
animals fed $42 \%$ cactus pear silage had greater intake average values $(p<0.01)$ than the diets with $0 \%$ and $21 \%$ cactus pear silage.

There was no interaction $(p>0.05)$ among the mineral absorption, digestibility coefficient and body water retention values in goats (Table 4 ). In addition, the proportions of cactus pear silage and the intermittent offers of water did not affect $(p>0.05)$ the mineral absorption coefficients in goats.

Table 3. Performance growth and nutrient intake in goats fed diets containing cactus pear silage and subjected to intermittent water offers.

\begin{tabular}{|c|c|c|c|c|c|c|c|c|c|c|}
\hline \multirow[t]{2}{*}{ Intake } & \multicolumn{3}{|c|}{$\begin{array}{c}\text { Cactus Pear Silage } \\
\text { (\% DM) }\end{array}$} & \multicolumn{3}{|c|}{ Water Offers (h) } & \multirow[t]{2}{*}{ SEM $^{2}$} & \multicolumn{3}{|c|}{$p$-value ${ }^{3}$} \\
\hline & 0 & 21 & 42 & $0 \mathrm{~h}$ & $24 \mathrm{~h}$ & $48 \mathrm{~h}$ & & CS & WO & $\mathrm{CS} \times \mathrm{WO}$ \\
\hline $\mathrm{FBW}^{1}, \mathrm{Kg}$ & 22.9 & 22.9 & 22.4 & 23.1 & 23.3 & 21.8 & 0.61 & 0.93 & 0.62 & 0.60 \\
\hline $\mathrm{TWG}^{1}, \mathrm{Kg}$ & 4.01 & 4.65 & 5.00 & 4.86 & 4.83 & 3.96 & 0.33 & 0.48 & 0.48 & 0.39 \\
\hline $\mathrm{ADWG}^{1}, \mathrm{~g} /$ day & 63.6 & 73.7 & 79.4 & 77.2 & 76.7 & 62.9 & 5.29 & 0.48 & 0.48 & 0.39 \\
\hline $\mathrm{FE}^{1}$ & 0.15 & 0.16 & 0.17 & 0.16 & 0.17 & 0.14 & 0.01 & 0.70 & 0.65 & 0.25 \\
\hline \multicolumn{11}{|l|}{ Daily intake (g/day) } \\
\hline Dry matter & 623 & 654 & 675 & 671 & 682 & 599 & 22.2 & 0.65 & 0.28 & 0.49 \\
\hline $\mathrm{DM}, \% \mathrm{BW}^{1}$ & 3.01 & 3.18 & 3.39 & 3.26 & 3.25 & 3.06 & 0.08 & 0.21 & 0.53 & 0.61 \\
\hline $\mathrm{DM}, \mathrm{BW}^{0.75}$ & 59.8 & 62.2 & 65.3 & 63.2 & 63.8 & 57.1 & 1.41 & 0.30 & 0.43 & 0.59 \\
\hline Crude protein & 80.1 & 92.8 & 92.9 & 92.3 & 90.9 & 82.7 & 3.12 & 0.16 & 0.40 & 0.45 \\
\hline Ether extract & 16.6 & 18.0 & 17.8 & 18.1 & 18.2 & 16.0 & 0.60 & 0.62 & 0.29 & 0.74 \\
\hline $\mathrm{NDF}_{\mathrm{ap}}$ & $291 \mathrm{a}$ & $230 \mathrm{~b}$ & $227 \mathrm{~b}$ & 263 & 263 & 222 & 10.7 & 0.02 & 0.16 & 0.56 \\
\hline NFC & $169 \mathrm{~b}$ & $244 a$ & $267 a$ & 227 & 226 & 215 & 10.9 & $<0.01$ & 0.55 & 0.30 \\
\hline TDN & $334 b$ & $401 \mathrm{~b}$ & $499 a$ & 399 & 404 & 431 & 19.2 & $<0.01$ & 0.68 & 0.29 \\
\hline $\mathrm{Ca}$ & $2.65 c$ & $4.27 \mathrm{~b}$ & $5.69 a$ & 4.08 & 4.23 & 4.28 & 0.269 & $<0.01$ & 0.89 & 0.51 \\
\hline $\mathrm{P}$ & 1.52 & 1.75 & 1.75 & 1.64 & 1.67 & 1.70 & 0.07 & 0.32 & 0.96 & 0.24 \\
\hline $\mathrm{Ca}: \mathrm{P}$ ratio & $1.74 \mathrm{c}$ & $2.44 \mathrm{~b}$ & $3.25 a$ & 2.49 & 2.53 & 2.52 & 3.84 & $<0.01$ & 0.93 & 0.23 \\
\hline $\mathrm{Mg}$ & $2.04 b$ & $2.69 a$ & $2.89 a$ & 2.53 & 2.61 & 2.48 & 0.12 & $<0.01$ & 0.87 & 0.23 \\
\hline $\mathrm{Na}$ & 0.83 & 0.88 & 0.84 & 0.88 & 0.86 & 0.82 & 0.34 & 0.81 & 0.76 & 0.29 \\
\hline K & $2.09 b$ & $2.19 b$ & $3.62 a$ & 2.51 & 2.69 & 2.70 & 0.17 & $<0.01$ & 0.76 & 0.25 \\
\hline
\end{tabular}

${ }^{1} \mathrm{BW}$ = Body weight; FBW = Final body weight; TWG = Total weight gain; Average daily weight gain (ADWG); $\mathrm{FE}=$ Feeding efficiency; ${ }^{2}$ Standard error of the mean (SEM); ${ }^{3}$ Means followed by different letters differ by Tukey's test $(p<0.05)$ to the following effects: $\mathrm{CS}=$ cactus pear silage; $\mathrm{WO}=$ intermittent water offers; and $\mathrm{CS} \times \mathrm{WO}=$ cactus pear silage and water offers interaction.

Table 4. Mineral absorption, nutrient digestibility and body water balance/retention in goats fed diets containing cactus pear silage and subjected to intermittent water offers.

\begin{tabular}{|c|c|c|c|c|c|c|c|c|c|c|}
\hline \multirow[t]{2}{*}{ Item } & \multicolumn{3}{|c|}{$\begin{array}{c}\text { Cactus Pear Silage } \\
(\% \text { DM) }\end{array}$} & \multicolumn{3}{|c|}{ Water Offers (h) } & \multirow[t]{2}{*}{ SEM $^{1}$} & \multicolumn{3}{|c|}{$p$-value ${ }^{2}$} \\
\hline & 0.0 & 21 & 42 & $\mathbf{0 h}$ & $24 \mathrm{~h}$ & $48 \mathrm{~h}$ & & CS & WO & $\mathrm{CS} \times \mathrm{WO}$ \\
\hline \multicolumn{11}{|l|}{ Mineral absorption (\%) } \\
\hline $\mathrm{Ca}$ & 59.2 & 60.0 & 59.2 & 58.7 & 59.5 & 60.3 & 10.9 & 0.94 & 0.85 & 0.93 \\
\hline $\mathrm{P}$ & 63.2 & 61.6 & 60.9 & 61.4 & 61.6 & 62.6 & 5.31 & 0.09 & 0.49 & 0.41 \\
\hline $\mathrm{Mg}$ & 70.3 & 71.2 & 71.5 & 71.4 & 70.6 & 71.1 & 7.23 & 0.81 & 0.91 & 0.74 \\
\hline $\mathrm{Na}$ & 71.4 & 70.7 & 70.5 & 71.0 & 70.8 & 70.8 & 1.52 & 0.06 & 0.77 & 0.67 \\
\hline $\mathrm{K}$ & 69.5 & 69.4 & 70.6 & 69.7 & 70.1 & 69.6 & 2.44 & 0.08 & 0.67 & 0.55 \\
\hline \multicolumn{11}{|c|}{ Nutrient digestibility (\%) } \\
\hline Dry matter & $66.2 \mathrm{c}$ & $68.7 \mathrm{~b}$ & $72.3 a$ & 68.5 & 69.1 & 69.3 & 4.51 & $<0.01$ & 0.94 & 0.50 \\
\hline Crude protein & $70.2 b$ & $71.5 \mathrm{ab}$ & $73.2 \mathrm{a}$ & 71.7 & 71.7 & 71.4 & 4.34 & 0.01 & 0.12 & 0.98 \\
\hline Ether extract & 68.1 & 68.9 & 68.9 & 68.2 & 69.0 & 68.5 & 3.42 & 0.52 & 0.23 & 0.32 \\
\hline $\mathrm{NDF}_{\mathrm{ap}}$ & 55.1 & 55.1 & 55.5 & 55.0 & 55.8 & 55.0 & 2.54 & 0.68 & 0.21 & 0.13 \\
\hline NFC & $84.0 \mathrm{~b}$ & $89.0 \mathrm{a}$ & $90.6 a$ & 87.3 & 86.9 & 89.2 & 7.05 & $<0.01$ & 0.13 & 0.08 \\
\hline TDN & $69.3 c$ & $72.0 \mathrm{~b}$ & $75.5 \mathrm{a}$ & 71.8 & 72.3 & 72.6 & 4.52 & $<0.01$ & 0.93 & 0.63 \\
\hline \multicolumn{11}{|c|}{ Body water intake $(\mathrm{Kg} /$ day $)$} \\
\hline Drinking & $1.11 \mathrm{a}$ & $0.52 b$ & $0.40 \mathrm{~b}$ & $0.83 \mathrm{~A}$ & $0.61 \mathrm{AB}$ & $0.58 \mathrm{~B}$ & 0.03 & $<0.01$ & 0.02 & 0.23 \\
\hline Feeding & $0.16 \mathrm{c}$ & $1.77 \mathrm{~b}$ & $3.13 a$ & 1.55 & 1.75 & 1.75 & 0.11 & $<0.01$ & 0.47 & 0.14 \\
\hline Total & $1.27 \mathrm{c}$ & $2.29 b$ & $3.53 a$ & 2.38 & 2.36 & 2.33 & 0.15 & $<0.01$ & 0.96 & 0.03 \\
\hline \multicolumn{11}{|c|}{ Body water excretion $(\mathrm{Kg} /$ day $)$} \\
\hline Urine & $0.29 \mathrm{c}$ & $0.55 b$ & $1.16 \mathrm{a}$ & 0.61 & 0.65 & 0.72 & 0.28 & $<0.01$ & 0.76 & 0.35 \\
\hline Feces & 0.16 & 0.23 & 0.24 & 0.20 & 0.22 & 0.22 & 0.11 & 0.67 & 0.76 & 0.35 \\
\hline Total & $0.45 c$ & $0.78 b$ & $1.40 \mathrm{a}$ & 0.81 & 0.85 & 0.94 & 0.39 & $<0.01$ & 0.45 & 0.07 \\
\hline Body water retention & $0.82 \mathrm{c}$ & $1.51 \mathrm{~b}$ & $2.13 a$ & 1.57 & 1.51 & 1.39 & 0.25 & $<0.01$ & 0.59 & 0.13 \\
\hline
\end{tabular}

${ }^{1}$ Standard error of the mean (SEM); ${ }^{2}$ Means followed by different letters differ by Tukey's test $(p<0.05)$ for the following effects: $\mathrm{CS}=$ cactus pear silage; $\mathrm{WO}=$ intermittent water offers; and $\mathrm{CS} \times \mathrm{WO}=$ cactus pear silage and water offers interaction. 
The intermittent water offers did not influence the DM, CP, ash, NDFap, NFC or TDN nutrient digestibility. However, DM, CP, EE, $\mathrm{NDF}_{\text {ap }}$ and NFC digestibility were influenced by the inclusion of cactus pear silage in the diets. The digestibility of DM $(p<0.01)$ and TDN $(p<0.001)$ was superior in the diet with $42 \%$ cactus pear silage compared to the $0 \%$ diet and was similar to the $21 \%$ cactus pear silage diet. Regarding CP $(p=0.01)$ and NFC $(p<0.01)$, goats fed $42 \%$ DM cactus pear silage presented greater digestibility and NFC digestibility, and there was no difference between the groups fed $0 \%$ and $21 \%$ cactus pear silage.

There was an interaction $(p=0.033)$ between the cactus pear silage and intermittent water offers for total water intake, which was not influenced by water balance in goats. The availability of cactus pear silage elevated the total water intake $(p<0.01)$ for the diets without silage and with 21 and $42 \%$ DM of cactus pear silage, while it did not influence the intermittent offers of water. Water offers did not affect $(p=0.96)$ total water intake for offers ad libitum or 24 and $48 \mathrm{~h}$ water restriction.

The drinking water intake at $48 \mathrm{~h}$ restriction was reduced $(p=0.02)$. There was no difference between the ad libitum and $24 \mathrm{~h}$ water restriction for drinking water intake. Water offers ad libitum presented an average value of $0.83 \mathrm{Kg} /$ day of drinking water. Drinking water intake was also influenced ( $p<0.05$ ) by the inclusion of cactus pear silage; goats receiving $21 \%$ and $42 \%$ cactus pear silage presented a reduction in drinking water when compared to goats that did not receive silage.

Feeding water intake $(p=0.47)$, total water intake $(p=0.96)$, urine water excretion $(p=0.76)$, total body water excretion $(p=0.45)$ and body water retention $(p=0.59)$ were not influenced by intermittent water offers.

However, cactus pear silage inclusion in the diets did influence feeding water intake $(p<0.01)$, total water intake $(p<0.01)$, urine water excretion $(p<0.01)$, total water excretion $(p<0.01)$ and body water retention $(p<0.01)$; a greater intake average was observed in the goats that received $42 \%$ cactus pear silage compared to the group that received $21 \%$ cactus pear silage, and the treatment without cactus pear silage inclusion presented lower feeding and total water intake by the goats. Feces water excretion was not influenced by cactus pear silage inclusion $(p=0.67)$ or intermittent water offers $(p=0.76)$.

\subsection{Ingestive Behavior}

There was no interaction $(p>0.05)$ between the studied factors for ingestive behavior variables (Table 5). The proportions of cactus pear silage in diets influenced the eating spent time $(p<0.01)$, which was greater in diets without cactus silage compared to the diets with $21 \%$ and $42 \%$ cactus pear silage, which were 66 and 88 minutes lower per day, respectively. The time spent ruminating decreased $(p=0.02)$ when there was an addition of $42 \%$ cactus pear silage compared to no cactus pear silage. The diet with $21 \%$ cactus pear silage did not significantly differ from the diets with $42 \%$ cactus pear silage or without cactus pear silage. The time spent idling of animals fed $42 \%$ cactus pear silage was greater than that with diets lacking cactus pear silage. The group of goats receiving $21 \%$ cactus pear silage had an average idling time of $901 \mathrm{~min} / \mathrm{d}$, which did not statistically differ from the 0 and $42 \%$ cactus pear silage groups.

There was an effect $(p<0.05)$ of silage on the eating efficiency rate $(\mathrm{g} \mathrm{DM} / \mathrm{h}$ and $\mathrm{g} \mathrm{NDF} / \mathrm{h})$ and ruminating (DM), which presented greater time in the diet with $42 \%$ cactus pear silage than in the diet without cactus pear silage and did not present a significant difference when compared with goats fed $21 \%$ cactus pear silage. Total chewing time $(\mathrm{min} / \mathrm{d})$ was similar between the diets of goats without and those with $21 \%$ cactus pear silage; however, the total chewing time was lower in the diets with $42 \%$ cactus pear silage than in the diets without cactus pear silage, and no significant difference was found when compared with goats fed $21 \%$ cactus pear silage. 
Table 5. Ingestive behavior of goats fed diets containing cactus pear silage and subjected to intermittent water offers.

\begin{tabular}{|c|c|c|c|c|c|c|c|c|c|c|}
\hline \multirow[t]{2}{*}{ Item } & \multicolumn{3}{|c|}{$\begin{array}{c}\text { Cactus Pear Silage } \\
(\% \text { DM) }\end{array}$} & \multicolumn{3}{|c|}{ Water Offers (h) } & \multirow[t]{2}{*}{ SEM $^{2}$} & \multicolumn{3}{|c|}{$p$-value ${ }^{3}$} \\
\hline & 0 & 21 & 42 & $\mathbf{O h}$ & $24 \mathrm{~h}$ & $48 \mathrm{~h}$ & & CS & WO & $\mathrm{CS} \times \mathrm{WO}$ \\
\hline \multicolumn{11}{|c|}{ Time spent activity $(\mathrm{min} / \mathrm{d})$} \\
\hline Eating & $248 \mathrm{a}$ & $182 b$ & $160 \mathrm{~b}$ & 204 & 218 & 170 & 12.3 & $<0.01$ & 0.17 & 0.27 \\
\hline Ruminating & $414 \mathrm{a}$ & $355 \mathrm{ab}$ & $303 b$ & 402 & 336 & 334 & 17.2 & 0.02 & 0.15 & 0.49 \\
\hline Idling & $778 b$ & $903 \mathrm{ab}$ & $977 a$ & 834 & 886 & 936 & 25.5 & $<0.01$ & 0.19 & 0.41 \\
\hline \multicolumn{11}{|l|}{ Efficiency rate $(\mathrm{g} / \mathrm{h})$} \\
\hline \multicolumn{11}{|c|}{ Dry Matter (DM) } \\
\hline Eating & $60.3 b$ & $86.2 \mathrm{ab}$ & $101 \mathrm{a}$ & 78.9 & 75.1 & 84.6 & 2.27 & 0.04 & 0.11 & 0.10 \\
\hline Ruminating & $36.1 b$ & $44.2 \mathrm{ab}$ & $53.5 \mathrm{a}$ & 40.1 & 48.7 & 43.0 & 1.10 & 0.04 & 0.13 & 0.17 \\
\hline \multicolumn{11}{|c|}{ Neutral Detergent Fiber (NDF) } \\
\hline Eating & $28.2 b$ & $30.3 \mathrm{ab}$ & $34.1 \mathrm{a}$ & 30.9 & 29.0 & 31.3 & 0.95 & 0.03 & 0.24 & 0.13 \\
\hline Ruminating & $16.9 \mathrm{~b}$ & $15.5 b$ & $18.0 \mathrm{a}$ & 15.7 & 18.8 & 16.0 & 1.15 & 0.04 & 0.24 & 0.12 \\
\hline $\mathrm{TCT}^{1}, \mathrm{~min} / \mathrm{d}$ & $663 a$ & $539 \mathrm{ab}$ & $464 b$ & 606 & 555 & 504 & 25.5 & $<0.01$ & 0.17 & 0.41 \\
\hline
\end{tabular}

${ }^{1}$ TCT $=$ Total chewing time; ${ }^{2}$ Standard error of the mean (SEM); ${ }^{3}$ Means followed by different letters differ by Tukey's test $(p<0.05)$ for the following effects: $\mathrm{CS}=$ cactus pear silage; $\mathrm{WO}=$ intermittent water offers; $\mathrm{CS} \times \mathrm{WO}=$ cactus pear silage and water offers interaction.

\subsection{Blood Metabolites}

There was no interaction of cactus silage level and water offers for blood metabolites $(p>0.05)$ in goats. The silage of cactus pear and intermittent water offers did not influence the serum concentrations of glucose, albumin, globulin, total protein, triglycerides or total cholesterol (mg/dL) (Table 6).

Table 6. Blood serum metabolites of goats fed diets containing cactus pear silage and subjected to intermittent water offers.

\begin{tabular}{|c|c|c|c|c|c|c|c|c|c|c|}
\hline \multirow[t]{2}{*}{$\begin{array}{l}\text { Blood Metabolites } \\
\text { (mg/dL of Blood) }\end{array}$} & \multicolumn{2}{|c|}{$\begin{array}{c}\text { Cactus Pear } \\
\text { Silage (\% DM) }\end{array}$} & \multicolumn{4}{|c|}{ Water Offers (h) } & \multirow[t]{2}{*}{ SEM $^{1}$} & \multicolumn{3}{|c|}{$p$-value ${ }^{2}$} \\
\hline & 0 & 21 & 42 & $\mathbf{0 h}$ & $24 \mathrm{~h}$ & $48 \mathrm{~h}$ & & CS & WO & $\mathrm{CS} \times \mathrm{WO}$ \\
\hline Glucose & 59.6 & 77.8 & 65.0 & 66.6 & 70.6 & 65.2 & 5.82 & 0.49 & 0.93 & 0.93 \\
\hline Albumin & 3.17 & 3.28 & 3.06 & 3.13 & 3.21 & 3.17 & 0.16 & 0.26 & 0.86 & 0.17 \\
\hline Globulin & 3.49 & 2.94 & 3.11 & 2.57 & 3.26 & 3.72 & 0.26 & 0.67 & 0.20 & 0.52 \\
\hline Total protein & 6.67 & 6.23 & 6.17 & 5.71 & 6.93 & 6.43 & 0.25 & 0.68 & 0.15 & 0.64 \\
\hline Triglycerides & 194 & 172 & 193 & 195 & 184 & 180 & 11.8 & 0.76 & 0.88 & 0.86 \\
\hline Cholesterol & 108 & 124 & 91.5 & 127 & 97.6 & 101 & 8.34 & 0.40 & 0.33 & 0.80 \\
\hline
\end{tabular}

\section{Discussion}

Cactus pear silage presented good fermentation with low effluent and loss of gasses, high DM recovery $(93 \%)$, high soluble carbohydrate content $(54 \%$ in $\mathrm{DM})$ and a $\mathrm{pH}$ value of 3.8 , which promote high lactic acid concentrations [14]. In addition, the mucilage avoided the effluent flowing down to the bottom of silos, minimizing losses during ensilage because the cactus silage was well preserved. It can be inferred that the silage did not influence the performance data since all animals received the same silage, which only changed the quantity offered.

The goats presented similar ADG values, which can be explained by the lack of differences in DMI. However, the mean ADG value $(76 \mathrm{~g} / \mathrm{d})$ was lower than expected $(100 \mathrm{~g} / \mathrm{d})$ according to the recommendations of NRC [6] because the DMI had average values lower than $730 \mathrm{~g} /$ day (Table 3), resulting in a total gain of $4.55 \mathrm{Kg}$ during the 63 experimental $\mathrm{d}$. In addition, the feed efficiency was similar between treatments, presenting an average value of $0.16(\mathrm{~g} / \mathrm{g})$ and demonstrating that the cactus silage did not influence feed efficiency and can be offered at a proportion of $42 \%$ in a goat kid's diet.

The reduction in NDF can be correlated to a reduction in $\mathrm{NDF}_{\mathrm{ap}}$ in the diet (Table 2) due to cactus pear silage inclusion, which was approximately $49.5,40.8$ and $35.7 \%$ at 0,21 and $42 \%$ inclusion, respectively. According to Cordova-Torres et al. [12], Silva et al. [9] and Felix et al. [13], cactus pear 
forage presented a low concentration of $\mathrm{NDF}_{\text {ap }}$ compared to other roughages, which is associated with high soluble carbohydrate concentrations that increase the NFC ingestion of goats and, consequently, the TDN [29], corroborating the findings of the present study. Several factors can be associated with feed ingestion control, including palatability, DM digestibility and ruminal degradation [30]. The increase in digestibility is not attributed to palm silage alone but to the diet as a whole, as the higher level of cactus pear increased the energy intake (NFC and TDN). Thus, by ingesting more cactus pear that has high digestibility, the total intake of energy is also increased. The DMI had a slight increase that was not significant in the statistical analysis.

Intermittent water offerings did not influence the nutrient intake of the goats. Bessa and Aganga [31] evaluated different intermittent offers of water in Tswana goats and did not observe any differences in DMI, which presented an average water intake of $751 \mathrm{~g} / \mathrm{d}$ with hydric offers every $72 \mathrm{~h}$. Misra and Singh [32] offered water at 0, 24 and $48 \mathrm{~h}$ to goats and did not observe any effect on DMI, demonstrating that goats are resilient animals that can adapt to intermittent water offers for up to $48 \mathrm{~h}$.

$\mathrm{Ca}, \mathrm{Mg}$ and $\mathrm{K}$ intake increased with the addition of cactus pear silage at $42 \%$. These results may be justified by the greater concentration of these minerals in cactus pear forage (Table 1). The cactus pear silage addition at $21 \%$ and $42 \%$ elevated the Ca intake compared to animals that did not receive silage in the diet. In this context, Ben Salem et al. [33] affirmed that diets based on forage cactus pear generally elevate $\mathrm{Ca}$ concentrations, and the absence of excess of this mineral may be correlated with the presence of oxalate, which is connected to $\mathrm{Ca}$ and makes $\mathrm{Ca}$ unavailable to the animal. Regarding $\mathrm{K}$, Segundo Neto et al. [34] observed that with the incorporation of the cactus pear forage in the diet, urinary excretion is increased by the greater water intake from the dietary component, as was observed in this experiment, and by the action of electrolytes with diuretic effects, which may have stimulated the increase in $\mathrm{K}$ intake.

Regarding $\mathrm{P}$ intake, $\mathrm{P}$ was not influenced by the studied factors, with average values of intake at $1.67 \mathrm{~g} / \mathrm{d}$. According to the NRC recommendations [6], the P intake may be $0.71 \mathrm{~g} / \mathrm{d}$ per goat, which is lower than that found in this study. The P concentrations in saliva are elevated with the increased availability of this mineral in the diet. The salivary secretions supply the rumen microbiota with a readily available source of $\mathrm{P}$, which, according to the NRC [6], is necessary for cellular growth and metabolism. However, excess $\mathrm{P}$ in the diet may interfere with Ca absorption, mainly when the ratio between these two minerals is under 1:5. In this study, the Ca:P ratio ranged between 1.74:1 and 3.25:1 in treatments with $0 \%$ and $42 \%$ cactus pear silage. In small ruminants, a ratio of Ca:P that is higher than 7:1 or lower than 1:1 may lead to the appearance of urolithiasis and affect the performance of the animal [35].

Although the intake of some minerals was increased with the inclusion of cactus silage in the diet of goats, it was not enough to cause changes in the mineral absorption coefficients, probably because $\mathrm{Ca}$ is in a calcium oxaloacetate form and is apparently unavailable to the ruminants [36]. The finding that there was no effect of the Ca:P ratio on absorption suggests that there is an adaptation of true Ca digestibility maintenance with regards to the varying intake or the Ca:P ratio. Certain minerals can have an effect on the transport and bioavailability of calcium in the body, and calcium transport in the body is enhanced by carbohydrates and by low luminal concentrations of sodium. This may explain the lower absorption of Ca in relation to the other minerals. According to the NRC [6], goats may present $\mathrm{Mg}$ and $\mathrm{K}$ absorption coefficients of $70 \%$ and $91 \%$, respectively.

The digestibility of DM, CP and NFC was positively influenced by the addition of cactus pear silage in the diet. These results might be associated with the low ADF and ADL concentrations (Table 2) and a greater concentration of NFC in the cactus pear silage, which probably increased ruminal degradation and nutrient digestion. Bispo et al. [7] affirmed that increasing NFC in the diet might favor rapid degradation in the rumen, quickly absorbing and increasing energy support and favoring microbial growth and digestion. According to Batista et al. [37], approximately $60 \%$ of the carbohydrates (in DM) of cactus pear forage are of rapid and medium degradability, and only $4.4 \%$ are unavailable; the carbohydrates are $12.9 \%$ starch, a relatively high value for general roughage. 
Thus, the high percentage of rapidly digested carbohydrates increased the microbial activity and the concentration of volatile fatty acids (VFAs), resulting in a reduction in $\mathrm{pH}$. Costa et al. [38] affirmed that in sheep fed cactus pear, the degradability was important for the synthesis of microbial protein in the rumen, stimulating ruminal microbiota and favoring cellulolytic activities; in response, the microbiota can increase available energy in the form of fatty acids and reduce the quantity of protein that escapes degradation in the rumen.

Due to its high water contents $( \pm 90 \%)$, the cactus pear silage increased the feeding water and influenced water excretion in urine to maintain equilibrium in the goats. However, total water intake was greater than water excretion, resulting in a positive water balance and more water retention in goats who received silage in the diet. The greater urinary water excretion was influenced by total water intake, which was greater in the group of goats that ingested $42 \%$ cactus pear silage. Animals that consume more water tend to eliminate more urine to maintain hydroelectrolyte equilibrium [39,40].

The intermittent water significantly influenced the drinking water intake because the goats that received ad libitum water presented a higher average daily intake $(0.83 \mathrm{Kg} / \mathrm{d})$ than the animals receiving intermittent supplies of water every $48 \mathrm{~h}(0.58 \mathrm{Kg} / \mathrm{d})$. However, the animals receiving intermittent supplies of water or restriction every $24 \mathrm{~h}(0.61)$ presented similar drinking water intake relative to goats who received ad libitum water. These goats ingested more water when it was available in an attempt to compensate for the lack of drinking water during the restriction days [39]. Thus, the total water intake was similar among the treatments.

Water availability is important in animal production in semiarid regions due to limited water supply, and animals in these regions that drink water at a low frequency may not meet producer needs [39]. During periods of water scarcity, a goat consumes less water due to its greater water use efficiency in relation to lambs, probably due to lower fecal and urinary losses and because their DMI and nutritional requirements are lower than lambs [41]. In this sense, the presence of any cactus pear silage in the diet can increase water use or excretion and therefore increases the need for ingestion. Neto et al. [34] and Araújo [42] affirmed that forage cactus pear may be an important source of water for animal watering in seasons of water scarcity. The observation of higher urinary volume produced by cactus pear forage diets in the in natura form is expected because urinary excretion is necessary to maintain homeostasis between water intake (both voluntary intake and feeding intake) and the excretion of water by the organism [43,44]. It has been proven that goats fed rations containing more than $30 \%$ cactus pear forage can stop drinking water and still maintain high urinary excretion [45].

The goats that did not receive cactus pear silage in their diets spent more time eating and ruminating because of the reduction in $\mathrm{NDF}_{\mathrm{ap}}$ and increase in NFC in the diets with more cactus pear silage (Table 2). In this context, some authors have affirmed that the time spent ruminating and chewing was influenced by the nature of the diet and seems to be proportional to the fiber content $[23,46]$. This also promoted increases in the eating and ruminating efficiency rate $(\mathrm{g} \mathrm{DM} / \mathrm{h})$ and decreases in the total chewing time $(\mathrm{min} / \mathrm{d})$. Costa et al. [47] evaluated the ingestive behavior of goats and sheep fed with increased concentrations of forage cactus pear as feed and observed a linear reduction; the authors associated this reduction with the reduction in fiber content in the ration and the increase in the percentage of cactus pear. Consequently, there was a decrease in $\mathrm{NDF}_{\mathrm{ap}}$ and an increase in the quantity of NFC contained in the ration, and thus, the quantity of physically effective fiber was reduced. Therefore, a reduction in the time spent eating and ruminating due to an increase in the soluble carbohydrate (NFC) content and a reduction in the fibrous content in the diet can promote a reduction in ruminal $\mathrm{pH}$, which contributes to ruminal acidosis. Neiva et al. [48] analyzed the effect of high intake proportions of cactus pear on the histological structure of the ruminal mucosa of sheep and observed that the animals that received diets with more cactus pear showed greater erosion in the stratum horny (keratinized layer) due to the presence of oxalates.

Regarding blood metabolites, there were no significant differences between cactus pear silage levels and intermittent offers of water. De Kalyan et al. [39] observed that the restriction of water intake during summer led to physiological and biochemical changes in Malpura breed sheep. However, the 
authors affirmed that when these stressful conditions were alleviated, their physiological condition returned to normal by an ad libitum supply of water. Given that the supply of water was constant, restriction every $48 \mathrm{~h}$ did not cause blood metabolite modifications in the goats in the present study. In addition, the goats met part of their water needs by consuming cactus pear silage, thus reducing the effects of this restriction.

\section{Conclusions}

Cactus pear silage inclusion at up to $42 \%$ for goats is recommended during periods of water shortage in semiarid and arid regions because it improves the eating and ruminating efficiency rates and body water retention and reduces drinking water ingestion without affecting the performance or health of the animal.

Author Contributions: R.O. and J.S.-J. contributed in funding acquisition and project administration. I.A. and I.N. contributed in the data study design, execution, data attainment and interpretation and in the manuscript writing. G.C. and G.A. contributed in the analysis and interpretation of data. E.S. and F.S. contributed in the execution of field tests and interpretation of analysis. L.B. and E.S.-F. contributed to the writing-review and editing of manuscript. All authors have read and agreed to the published version of the manuscript.

Funding: This research received no external funding from the National Council for Scientific and Technological Development (Brazil) or from the Bahia State Research Foundation.

Acknowledgments: This research was supported by the Coordination for the Improvement of Higher Education Personnel (CAPES), Coordination for the Improvement of Greater Education Personnel and Brazilian Agricultural Research Corporation (EMBRAPA, Brazil), and Brazilian National Council for Scientific and Technological Development (CNPq) with Grants Number 441321/2017-3.

Conflicts of Interest: The authors declare no conflict of interest.

\section{References}

1. Salem, H.B.; Smith, T. Feeding strategies to increase small ruminant production in dry environments. Small Rumin. Res. 2008, 77, 174-194. [CrossRef]

2. Schlecht, E.; Dickhöfer, U.; Predotova, M.; Buerkert, A. The importance of semi-arid natural mountain pastures for feed intake and recycling of nutrients by traditionally managed goats on the Arabian Peninsula. J. Arid Environ. 2011, 75, 1136-1146. [CrossRef]

3. Araújo, G.G.L.; Voltolini, T.V.; Chizzotti, M.L.; Turco, S.H.N.; Carvalho, F.F.R. Water and small ruminant production. Rev. Bras. Zootec. 2010, 39, 326-336. [CrossRef]

4. Oliveira, A.B.; Sousa, W.H.; Oliveira, F.G.; Cartaxo, F.Q.; Filho, E.C.P.; Ramos, J.P.D.F.; Cunha, M.D.G.; Ferreira, J.M.D.S. Productive and economic performance of goats of different genetic groups. Rev. Bras. Saúde Prod. Anim. 2018, 19, 381-390. [CrossRef]

5. Salem, H.B. Nutritional management to improve sheep and goat performances in semiarid regions. Rev. Bras. Zootec. 2010, 39, 337-347. [CrossRef]

6. National Research Council (NRC). Nutrient Requirements of Small Ruminants: Sheep, Goats, Cervids and New World Camelids, 7th ed.; National Academy Press: Washington, DC, USA, 2007; pp. 1-347.

7. Bispo, S.V.; Ferreira, M.A.; Veras, A.S.C.; Batista, Â.M.V.; Pessoa, R.A.S.; Bleuel, M.P. Spineless cactus in replacement of elephant grass hay. Effect on intake, apparent digestibility and ruminal fermentation characteristics in sheep. Rev. Bras. Zootec. 2007, 36, 1902-1909. [CrossRef]

8. Salem, H.B.; Abidi, S. Recent advances on the potential use of Opuntia spp. in livestock feeding. Acta Hortic. 2009, 811, 317-324. [CrossRef]

9. da Silva, A.P.G.; de Souza, C.C.E.; Ribeiro, J.E.S.; dos Santos, M.C.G.; de Souza Pontes, A.L.; Madruga, M.S. Physical, chemical and bromatological characteristics of the giant forage cactus (Opuntia ficus-indica) and small forage cactus (Nopalea cochenillifera) from Paraíba state (Brazil). Rev. Bras. Tecnol. Agroin. 2015, 9, $1810-1820$.

10. Goveia, J.S.S.; de Oliveira, V.S.; de Arruda Santos, G.R.; Melo, K.D.A.; de Oliveira, A.G.; Melo, M.V.A. Partial replacement of corn by forage cactus in the diets of lactating goats. Sem. Ciênc. Agrár. 2016, 37, 969-976. [CrossRef] 
11. Alves, F.A.L.; Andrade, A.P.; Bruno, R.L.A.; Santos, D.C. Study of the variability, correlation and importance of chemical and nutritional characteristics in cactus pear (Opuntia and Nopalea). Afr. J. Agric. Res. 2016, 11, 2882-2892.

12. Cordova-Torres, A.V.; Mendoza-Mendoza, J.C.; Bernal-Santos, G.; García-Gasca, T.; Kawas, J.R.; Costa, R.G.; Mondragon Jacobo, C.; Andrade-Montemayor, H.M. Nutritional composition, in vitro degradability and gas production of Opuntia ficus indica and four other wild cacti species. Life Sci. J. 2015, 12, 42-54.

13. Felix, S.C.R.; Pessoa, R.A.S.; de Andrade Ferreira, M.; Soares, L.F.P.; de Lima Silva, J.; de Abreu, K.S.F.; de Melo, A.C.C. Intake, performance, and carcass characteristics of lambs fed spineless cactus replacing wheat bran. Trop. Anim. Health Prod. 2016, 48, 465-468. [CrossRef] [PubMed]

14. Gusha, J.; Halimani, T.E.; Ngongoni, N.T.; Ncubec, S. Effect of feeding cactus-legume silages on nitrogen retention, digestibility and microbial protein synthesis in goats. Anim. Feed Sci. Technol. 2016, 206, 1-7. [CrossRef]

15. Mokoboki, K.; Sebola, N.; Matlabe, G. Effects of molasses levels and growing conditions on nutritive value and fermentation quality of Opuntia cladodes silage. J. Anim. Plant Sci. 2016, 28, 488-495.

16. Jobim, C.C.; Nussio, L.G.; Reis, R.A.; Schmidt, P. Methodological advances in evaluation of preserved forage quality. Rev. Bras. Zootec. 2007, 36, 101-119. [CrossRef]

17. Bolsen, K.K.; Lin, C.; Brent, B.E.; Feyerherm, A.M.; Urban, J.E.; Aimutis, W.R. Effect of silage additives on the microbial succession and fermentation process of alfalfa and corn silages. J. Dairy Sci. 1992, 75, 3066-3083. [CrossRef]

18. Kung, L.; Shaver, R. Interpretation and use of silage fermentation analysis reports. Focus Forage 2001, 3, 1-5.

19. Association of Official Analytical Chemistry (AOAC). Official Methods of Analysis, 19th ed.; Association of Official Analytical Chemistry: Washington, DC, USA, 2012.

20. Van Soest, P.J.; Robertson, J.B.; Lewis, B.A. Methods for dietary fiber, neutral detergent fiber, and nonstarch polysaccharides in relation to animal nutrition. J. Dairy Sci. 1991, 74, 3583-3597. [CrossRef]

21. Senger, C.C.D.; Kozloski, G.V.; Sanchez, L.M.B.; Mesquita, F.R.; Alves, T.P.; Castagnino, D.S. Evalution of autoclave procedures for fibre analysis in forage and concentrate feedstuffs. Anim. Feed Sci. Technol. 2008, 146, 169-174. [CrossRef]

22. Licitra, G.; Hernandez, T.M.; Van Soest, P.J. Standardization of procedures for nitrogen fractionation of ruminant feeds. Anim. Feed Sci. Technol. 1996, 57, 347-358. [CrossRef]

23. Mertens, D.R. Creating a system for meeting the fiber requirements of dairy cows. J. Dairy Sci. 1997, 80, 1463-1481. [CrossRef]

24. Devendra, C. Feeding and nutrition of goats. In Digestive Physiology and Nutrition of Ruminants, 2nd ed.; Church, D.C., Ed.; O and A Books: Corvallis, OR, USA, 1980; pp. 239-256.

25. Martin, P.; Bateson, P. Measuring Behaviour, 2nd ed.; Cambridge University Press: Cambridge, UK, 1993; 222p.

26. Bürger, P.J.; Pereira, J.C.; Queiroz, A.C.; Silva, J.F.C.; Valadares Filho, S.C.; Cecon, P.R.; Casali, A.D.P. Ingestive behavior in Holstein calves fed diets with different concentrate levels. Rev. Bras. Zootec. 2000, 29, $236-242$. [CrossRef]

27. Bezerra, L.R.; Ferreira, A.F.; Alves Camboim, E.K.; Justiniano, S.V.; Gomes, B.B.; Rocha Machado, P.C. Profile hematological of goat clinical healthy servants in Cariri paraibano. Ciênc. Agrotecnol. 2008, 32, 955-960. [CrossRef]

28. Statistical Analysis System Institute (SAS). SAS User's Guide: Statistics, version 9.4; SAS Institute Inc.: Cary, NC, USA, 2014.

29. Ben Salem, H.; Abdouli, H.; Nefzaoui, A.; El-Mastouria, A.; Ben Salem, L. Nutritive value, behaviour and growth of Barbarine lambs fed on oldan saltbush (Atriplex nummularia L.) and supplemented or not with barley grains or spineless cactus (Opuntia ficus indica f. inermis) pads. Small Rumin. Res. 2005, 59, 229-238. [CrossRef]

30. Costa, J.B.; Oliveira, R.L.; Silva, T.M.; Ribeiro, R.D.X.; Silva, A.M.; Leão, A.G.; Bezerra, L.R.; Rocha, T.C. Intake, digestibility, nitrogen balance, performance, and carcass yield of lambs fed licuri cake. J. Anim. Sci. 2016, 94, 2973-2980. [CrossRef]

31. Bessa, A.T.; Aganga, A.A. Responses of Tswana goats to various lengths of water deprivation. S. Afr. J. Anim. Sci. 2000, 30, 87-91.

32. Misra, A.K.; Singh, K. Effect of water deprivation on dry matter intake, nutrient utilization and metabolic water production in goats under semi-arid zone of India. Small Rumin. Res. 2002, 46, 159-165. [CrossRef] 
33. Ben Salem, H.; Nefzaoui, A.; Ben Salem, L. Spineless cactus (Opuntia ficus indica f. inermis) and oldman saltbush (Atriplex nummularia L.) as alternative supplements for growing Barbarine lambs given straw-based diets. Small Rumin. Res. 2004, 51, 65-73. [CrossRef]

34. Neto, J.P.; Soares, P.C.; Batista, Â.M.V.; Andrade, S.F.J.; Andrade, R.P.X.; Lucena, R.B.L.; Guim, A. Water balance and renal excretion of metabolites in sheep fed foragecactus (Nopalea cochenillifera Salm Dyck). Pesqui. Vet. Bras. 2016, 36, 322-328.

35. Riet-Correa, F.; Simões, S.V.D.; Vasconcelos, J.D. Urolithiasis in sheep and goats. Pesqui. Vet. Bras. 2008, 28, 319-322. [CrossRef]

36. Çürek, M.; Özen, N. Feed value of cactus and cactus silage. Turk. J. Vet. Anim. Sci. 2004, 28, 633-639.

37. Batista, A.M.; Mustafa, A.F.; Mcallister, T.; Wang, Y.; Soita, H.; McKinnon, J.J. Effects of variety on chemical composition, in situ nutrient disappearance and in vitro gas production of spineless cacti. J. Sci. Food Agric. 2003, 83, 440-445. [CrossRef]

38. Costa, R.G.; Treviño, I.H.; Medeiros, G.R.; Medeiros, A.N.; Pinto, T.F.; Oliveira, R.L. Effects of replacing corn with cactus pear (Opuntia ficus indica Mill) on the performance of Santa Inês lambs. Small Rumin. Res. 2012, 102, 13-17. [CrossRef]

39. De, K.; Kumar, D.; Singh, A.K.; Kumar, K.; Sahoo, A.; Naqvi, S.M.K. Resilience of Malpura ewes on water restriction and rehydration during summer under semi-arid tropical climatic conditions. Small Rumin. Res. 2015, 133, 123-127. [CrossRef]

40. Jaber, L.S.; Barbour, E.K.; Abi-Said, M.R.; Chedid, M.; Giger-Reverdin, S.; Duvaux-Ponter, C.; Morand-Fehr, P.; Hamadeh, S.K. Responses to repeated cycles of water restriction in lactating Shami goats. J. Appl. Anim. Res. 2015, 43, 39-45. [CrossRef]

41. Alamer, M. Effect of water restriction on lactation performance of Aardi goats under heat stress conditions. Small Rumin. Res. 2009, 84, 76-81. [CrossRef]

42. Araújo, G.G.L. Impacts of climate change on water resources and animal production in semi-arid regions. Rev. Bras. Geogr. Fís. 2015, 8, 598-609. [CrossRef]

43. Tegegne, F.; Kijora, C.; Peters, K.J. Study on the optimal level of cactus pear (Opuntia ficus-indica) supplementation to sheep and its contribution as source of water. Small Rumin. Res. 2007, 72, 157-164. [CrossRef]

44. Vieira, E.L.; Batista, A.M.V.; Guim, A.; Carvalho, F.F.; Nascimento, A.C.; Araújo, R.F.S.; Mustafa, A. Effects of hay inclusion on intake, in vivo nutrient utilization and ruminal fermentation of goats fed spineless cactus (Opuntia ficus indica Mill) based diets. Anim. Feed Sci. Technol. 2008, 141, 199-208. [CrossRef]

45. Araújo, P.R.B.; Ferreira, M.A.; Brasil, L.H.A.; Santos, D.C.; Lima, R.M.B.; Véras, A.S.C.; Santos, M.V.F.; Bispo, S.V.; Azevedo, M. Replacement of corn by forage cactus in the total mixed rations for crossbreed lactating cows. Rev. Bras. Zootec. 2004, 33, 1850-1857. [CrossRef]

46. Van Soest, P.J. Nutritional Ecology of the Ruminant, 2nd ed.; Cornell University Press: New York, NY, USA, 1994; 476p.

47. Costa, R.G.; Beltrão Filho, E.M.; de Medeiros, A.N.; Givisiez, P.E.N.; do Egypto, R.D.C.R.; Melo, A.A.S. Effects of increasing levels of cactus pear (Opuntia ficus-indica L. Miller) in the diet of dairy goats and its contribution as a source of water. Small Rumin. Res. 2009, 82, 62-75.

48. Neiva, G.S.M.; Mota, D.L.; Batista, Â.M.V.; Sousa-Rodrigues, C.F.D. Mucous membrane of the rumen of ovines, fed with spineless, forrage cactus or palm (Barbary Fig) (Opuntia ficus indica Mil): Hystochemical study by means of light microscopy. Int. J. Morphol. 2006, 24, 723-728. [CrossRef]

(C) 2020 by the authors. Licensee MDPI, Basel, Switzerland. This article is an open access article distributed under the terms and conditions of the Creative Commons Attribution (CC BY) license (http://creativecommons.org/licenses/by/4.0/). 